\title{
Expression and significance of quantum dots in RAW 264.7 macrophages
}

\author{
CHONG LI ${ }^{1}$, PANPAN ZHANG ${ }^{2}$, YANMING HAO ${ }^{1}$, DAWEI HE ${ }^{2}$, YIXIN SHEN ${ }^{3}$ and RONGZHU LU ${ }^{4}$ \\ Departments of ${ }^{1}$ Orthopedics and ${ }^{2}$ Laboratory, The First People's Hospital of Kunshan, Jiangsu University, Kunshan, \\ Jiangsu 215300; ${ }^{3}$ Department of Orthopedics, The Second Affiliated Hospital of Soochow University, Suzhou, Jiangsu 215004; \\ ${ }^{4}$ Laboratory Center, The First People's Hospital of Kunshan, Jiangsu University, Kunshan, Jiangsu 215300, P.R. China
}

Received January 17, 2017; Accepted April 23, 2018

DOI: $10.3892 / \mathrm{ol} .2018 .9362$

\begin{abstract}
The aim of the present study was to investigate the clinical application and utility of $\mathrm{CdSe} / \mathrm{ZnS}$ quantum dots (QDs) in tracing RAW 264.7 macrophages. RAW 264.7 cells and QDs at various concentrations were co-cultured for $24 \mathrm{~h}$, and the fluorescence intensity of the macrophages was determined at various time points. The mRNA expression levels of genes encoding inflammatory cytokines [tumor necrosis factor (TNF)- $\alpha$ and interleukin (IL)-1 $\beta$ ] were determined, and cellular assays were performed to investigate the activation, proliferation and apoptosis of RAW 264.7 cells. The QDs were engulfed by the macrophages, and the fluorescence intensity of RAW 264.7 cells increased with increasing concentration and time. The IL-1 $\beta$ mRNA level increased significantly at $50 \mu \mathrm{g} / \mathrm{ml}$ QDs, and that of TNF- $\alpha$ increased significantly at $100 \mu \mathrm{g} / \mathrm{ml}$ QDs. Accelerated proliferation of RAW 264.7 cells was observed at 50 and $100 \mu \mathrm{g} / \mathrm{ml}$ QDs; however, no increase in apoptosis of RAW 264.7 cells was observed in co-culture. CdSe/ZnS QDs may be used as tracers due to the fluorescence intensity of RAW 264.7 cells increasing with increasing QD concentration and time, resulting in the activation of macrophages and significant increases in proliferation at 50 and $100 \mu \mathrm{g} / \mathrm{ml}$ QDs compared with in the absence of QDs. The change in QD concentration was not significantly associated with the proliferation and apoptosis of RAW 264.7 macrophages.
\end{abstract}

\section{Introduction}

Semiconductor nanocrystals, also known as quantum dots (QDs), which contain elements in groups III-V, II-VI or IV (1), have become an important tool in biomedical research. These

Correspondence to: Dr Yanming Hao, Department of Orthopedics, The First People's Hospital of Kunshan, Jiangsu University, 91 Qianjin West Road, Kunshan, Jiangsu 215300, P.R. China E-mail: cnchongli@163.com

Key words: CdSe/ZnS quantum dots, macrophages, tumor necrosis factor- $\alpha$, interleukin- $1 \beta$ nanometer-sized inorganic nanomaterials, with notable optical and electronic properties, exhibit distinct advantages over traditional fluorescent organic dyes, including improved signal brightness, high quantum yield, increased photostability, tunable broad excitation and narrow emission spectra (2), particularly for quantitative and long-term fluorescence imaging and detection (3). QDs of various sizes emit light of various wavelengths following excitation by the same light source (4); therefore, compared with conventional organic fluorescent dyes, QDs may be used effectively as biomarkers, as well as unique optical properties, particularly in cell labeling and clinical targeting bio-imaging (5). Upon entry into cells, QDs can be localized in various subcellular compartments, such as the cytoplasm and lysosomes, depending on their surface charge (6). Fluorescent QDs can be conjugated with bioactive moieties, including antibodies, peptides, aptamers or small-molecule ligands, to target specific biological events and cellular structures, including labeling neoplastic cells, cell membrane receptors, DNA or peroxisomes (7). QDs have exhibited notable promise in various biomedical applications, including labeling of cellular proteins, sensitive cellular imaging, real-time tracking, fluorescence resonance energy transfer sensors, visible drug carriers, in vivo animal imaging and cancer theranostics (8).

It is necessary to label the adoptive cells, targeting agents or drugs that are injected in vivo in biomedical research and clinical targeting therapies, to trace their biological behavior or in vivo kinetics (9). Additionally, the in vivo applications vary from in vitro studies, and rely markedly on biocompatibility with monocytes and macrophages when used for tracing in vivo (10). Macrophages serve important roles in particle clearance and inflammatory reactions (11), are crucial effectors of innate immunity in the primary responses to pathogens (12) and participate in homeostasis and tissue regeneration (13). Upon activation, macrophages induce a variety of biological effects, such as mediating in vivo inflammatory responses and specific immune responses, thus they are involved in the occurrence and development of a number of diseases (14).

A previous study demonstrated that charged QDs may enter macrophages more efficiently than neutral QDs, and negative QDs are internalized more efficiently than positive QDs; however, positive QDs exhibit severe cytotoxicity, compared with negative QDs (15). Therefore, the aim of 
the present study was to determine the biocompatibility of $\mathrm{CdSe} / \mathrm{ZnS}$ QDs with monocytes and macrophages to provide a theoretical and experimental basis for future applications of in vivo QD labeling.

Macrophage clonal stimulating factor induces osteoclast differentiation factor, which in turn induces osteoclast formation. The activity of a macrophage determines the destruction of giant cell tumor of bone (16). Giant cell tumor of bone can be surgically removed; however, other treatments, including biological therapy and clinical targeted therapy, remain in the initial stages of development. In the present study, the intake of QDs by RAW 264.7 macrophages was investigated in order to determine the role of macrophages as markers of giant cell tumors of bone in vivo.

\section{Materials and methods}

Co-culture of QDs with RAW 264.7 cells. RAW 264.7 macrophages [Cell Bank of Type Culture Collection of Chinese Academy of Sciences (Shanghai, China)] were cultured and passaged in $10 \%$ fetal bovine serum-containing high-glucose Dulbecco's modified Eagle's medium (Sigma-Aldrich; Merck KGaA, Darmstadt, Germany). When the cells reached $80 \%$ confluence, they were digested using trypsin, sampled and counted using an inverted microscope (x400 magnification; Ti-S; Nikon, Tokyo, Japan) followed by seeding into 96-well plates at a density of $2 \times 10^{4}$ cells/well. Subsequently, the cells were cultured in $10 \%$ fetal bovine serum-containing high-glucose Dulbecco's modified Eagle's medium (DMEM; Sigma-Aldrich; Merck KGaA, Darmstadt, Germany) for $4 \mathrm{~h}$ at room temperature and following adherence to the wall of the plate, various concentrations $(0,10,50$ and $100 \mu \mathrm{g} / \mathrm{ml})$ of QDs (water-soluble CdSe/ZnS QDs; Q2565; emission wavelength, 565 nm; Wuhan Jiayuan Quantum Dot Technological Development Co., Ltd., Wuhan, China) were added for co-culture at room temperature. The diameter of the $\mathrm{CdSe} / \mathrm{ZnS}$ core/shell QDs was 9.79 $\pm 2.185 \mathrm{~nm}$, and the CdSe/ZnS QDs were carboxylate functionalized. Following different incubation periods ( 1 or $2 \mathrm{~h}$ ), a fluorescence microscope (x400 magnification) was used to observe the cells, and images were captured. Alternatively, the cells in the wells were washed with PBS twice to remove the non-macrophage-ingested QDs and then harvested for subsequent analysis. In subsequent experiments, the duration of co-culture of QDs with macrophages was $18 \mathrm{~h}$ at room temperature unless stated otherwise.

Flow cytometry. Trypsin-digested RAW 264.7 macrophages were filtered to prepare a single cell suspension and the fluorescence signal intensity of the QDs in the cells was detected directly using a flow cytometer (FACSCalibur ${ }^{\mathrm{TM}}$; BD Biosciences, Franklin Lakes, NJ, USA). Alternatively, an annexin V-fluorescein isothiocyanate kit (eBioscience; Thermo Fisher Scientific, Inc., Waltham, MA, USA) was added to the cell suspension for $30 \mathrm{~min}$ of labeling at $4^{\circ} \mathrm{C}$. Following washing with buffer ( $\mathrm{NaCl} 137 \mathrm{mmol} / 1, \mathrm{KCl} 2.7 \mathrm{mmol} / 1$, $\mathrm{Na}_{2} \mathrm{HPO}_{4} 10 \mathrm{mmol} / \mathrm{l}, \mathrm{KH}_{2} \mathrm{PO}_{4} 2 \mathrm{mmol} / \mathrm{l}, \mathrm{pH}$ 7.2 7.4) twice, propidium iodide (eBioscience; Thermo Fisher Scientific, Inc.) was added, followed by the immediate detection of apoptosis of RAW 264.7 cells using a flow cytometer and analyzed by FlowJo (version 7.2; FlowJo LLC, Ashland, OR, USA)
Reverse transcription-quantitative polymerase chain reaction (RT-qPCR). The cultured cells were centrifuged $(6,000 \mathrm{x} \mathrm{g}$, $10 \mathrm{~min}$ at $4^{\circ} \mathrm{C}$ ) to discard the medium, washed twice with PBS and then added to $1 \mathrm{ml}$ RNAiso Plus reagent (Takara Biotechnology Co., Ltd., Dalian, China), followed by repetitive pipetting to ensure complete contact of the cells with the reagent for $\sim 10 \mathrm{~min}$. Following lysis using trypsin on ice for $5 \mathrm{~min}$, the cell mixture was transferred into RNase-free Eppendorf tubes, gently agitated for 5 min with $200 \mu 1$ pre-cooled chloroform $\left(4^{\circ} \mathrm{C}\right)$ and left to stand for $10 \mathrm{~min}$ at $4^{\circ} \mathrm{C}$. Following centrifugation at $6,500 \mathrm{xg}$ for $10 \mathrm{~min}$ at $4^{\circ} \mathrm{C}$, the mixture was divided into three layers, among which the supernatant was carefully withdrawn and transferred into another clean Eppendorf tube. To this new Eppendorf tube, $500 \mu \mathrm{l}$ isopropanol was added. The tube was shaken gently at $4^{\circ} \mathrm{C}$ and left to stand for $10 \mathrm{~min}$ at $4^{\circ} \mathrm{C}$. The new Eppendorf tube was centrifuged at $6,500 \mathrm{xg}$ for $10 \mathrm{~min}$ at $4^{\circ} \mathrm{C}$. The supernatant was discarded and $1 \mathrm{ml} \mathrm{75 \%}$ ethanol solution [750 $\mu \mathrm{l}$ of ethanol and $250 \mu \mathrm{l}$ of diethyl pyrocarbonate (DEPC)-treated water] was added to the precipitate, RNA was dissolved again for 2-3 min and centrifuged at 6,500 x g for $5 \mathrm{~min}$ at $4^{\circ} \mathrm{C}$ and. The precipitate was then dried and the RNA pellet was dissolved in the appropriate amount of DEPC-treated water (5-20 $\mu \mathrm{l})$. The concentration of the total RNA was detected using a nucleic acid detector (CFX96, Bio-Rad Laboratories, Inc., Hercules, CA, USA), and the $\mathrm{A}_{260} / \mathrm{A}_{280}$ ratio of between 1.8 and 2.0 was determined.

First-strand cDNA was produced using an Invitrogen SuperScript cDNA synthesis kit (Invitrogen; Thermo Fisher Scientific, Inc.). The reaction comprised $2 \mu \mathrm{g}$ total RNA template, $1 \mu 1$ oligo(dT) $)_{18}$ primer, $1 \mu 110 \mathrm{mM}$ dNTP mixture and enzyme-free ultrapure water to a final volume of $12 \mu \mathrm{l}$. The reaction tube was incubated at $65^{\circ} \mathrm{C}$ for $5 \mathrm{~min}$ and then immediately placed on ice for $\sim 5 \mathrm{~min}$. Following centrifugation $\left(6,000 \times \mathrm{g}, 10 \mathrm{~min}\right.$ at $\left.4^{\circ} \mathrm{C}\right), 4 \mu 15 \mathrm{X}$ Reaction Buffer, $1 \mu$ l RiboLock ${ }^{\mathrm{TM}}$ nuclease inhibitor and $2 \mu 10.1 \mathrm{M}$ dithiothreitol were added, followed by mixing gently and incubating for $2 \mathrm{~min}$ at $37^{\circ} \mathrm{C}$. Moloney murine leukemia virus reverse transcriptase $(1 \mu \mathrm{l})$ was then added and mixed gently for reverse transcription in a LightCycler 480 System RT-PCR instrument (Roche Diagnostics, Basel, Switzerland) with alternating cycles of $37^{\circ} \mathrm{C}$ for $50 \mathrm{~min}$ and $70^{\circ} \mathrm{C}$ for $15 \mathrm{~min}$.

The reaction was then terminated, and the products were collected, and the qPCR mixture contained: $1 \mu \mathrm{l}$ cDNA; $0.5 \mu$ l each of upstream and downstream primers; $5 \mu \mathrm{l} \mathrm{SYBR}{ }^{\circledR}$ Green (Takara Biotechnology Co., Ltd.); and $3 \mu \mathrm{l}$ double-distilled water. The reaction conditions were: Pre-denaturation at $95^{\circ} \mathrm{C}$ for $30 \mathrm{sec}$, followed by 40 cycles of denaturation at $95^{\circ} \mathrm{C}$ for $5 \mathrm{sec}$, annealing for $20 \mathrm{sec}(\mathrm{TNF}-\alpha$ : $58^{\circ} \mathrm{C}$, IL- $1 \beta$ : $59^{\circ} \mathrm{C}, \beta$-actin: $57^{\circ} \mathrm{C}$ ) and extension at $72^{\circ} \mathrm{C}$ for $30 \mathrm{sec}$. The primer sequences were: Tumor necrosis factor (TNF)- $\alpha$, sense 5'-GAACTGGCAGAAGAGGCACT-3', and antisense 5'-GGTCTGGGCCATAGAACTGA-3'; interleukin (IL)-1 $\beta$, sense 5'-TGTGAAATGCCACCTTTTGA-3', and antisense 5'-TGAGTGATACTGCCTGCCTG-3'; and $\beta$-actin (internal reference), sense 5'-TGGAATCCTGTGGCATCC ATGAAAC-3', and antisense 5'-TAAAACGCAGCTCAG TAACAGTCCG-3'. For relative quantitative analysis, the $2^{-\Delta \Delta \mathrm{Cq}}$ method was used (17). 
Detection of cell proliferation. RAW 264.7 cells in the exponential growth phase were sampled, a cell suspension was prepared once the DMEM was washed away using HBSS and digested by $0.25 \%$ pancreatin for 5-10 $\mathrm{min}$ and the cells were seeded into 96 -well plates at a volume as $\sim 100 \mu \mathrm{l} /$ well for $4 \mathrm{~h}$ culture at $37^{\circ} \mathrm{C}$ and an atmosphere containing $5 \%$ $\mathrm{CO}_{2}$. When the cells adhered to the wall, QDs were added and co-cultured at $37^{\circ} \mathrm{C}$ for $18 \mathrm{~h}$. At $4 \mathrm{~h}$ prior to the end of the incubation, $10 \mu \mathrm{l}$ Cell Counting Kit-8 (CCK-8; Dojindo Molecular Technologies, Inc., Kumamoto, Japan) was added to each well and incubated at $37^{\circ} \mathrm{C}$ for $18 \mathrm{~h}$. The optical density of each well was determined at $450 \mathrm{~nm}$ using an ELISA subsequent to culture (BioTek Instruments, Inc., Winooski, VT, USA).

Statistical analysis. GraphPad Prism software (version 6.0; GraphPad Software, Inc., La Jolla, CA, USA) was used to analyze the experimental data. The data are presented as the mean \pm the standard error of the mean. The multiple group comparison used a two-way analysis of variance with Fisher's least significant difference post-hoc test. $\mathrm{P}<0.05$ was considered to indicate a statistically significant difference.

\section{Results}

Macrophages engulf QDs. Fig. 1A demonstrates that the co-culture of RAW 264.7 cells with various concentrations of QDs enabled the macrophages to become labeled with fluorescent signals, which were detected using flow cytometry. The intensity of the fluorescence signal was notably associated with the concentration of the co-cultured QDs. At a QD concentration of $10 \mu \mathrm{g} / \mathrm{ml}$, the fluorescence intensity was weak, whereas at $50 \mu \mathrm{g} / \mathrm{ml}$, the fluorescence intensity inside the macrophages was notably increased. The results also indicated that the fluorescence intensity was stronger in the $1 \mathrm{~h}$ co-culture group, compared with the $2 \mathrm{~h}$ co-culture group. Microscopic observations (Fig. 1B) also demonstrated that the macrophages exhibited strong fluorescence signals following engulfment of QDs. The results indicated that macrophages are able to engulf a specific concentration of QDs, and are thus labeled with strong fluorescence signals.

Furthermore, the dynamic changes of fluorescence signal intensity, following QDs $(50 \mu \mathrm{g} / \mathrm{ml})$ being co-cultured with the macrophages, were observed. The results (Fig. 1C) demonstrated that with extended co-incubation time, the fluorescence signals inside the macrophages increased, reaching a peak at $18 \mathrm{~h}$. The results indicated that the QD labeling increased in a time-dependent manner.

QDs promote macrophages to secrete inflammatory cytokines. Macrophages are important natural immune cells, which can be activated to secrete inflammatory cytokines (18) To observe whether QDs were able to activate the macrophages directly, the expression levels of the genes encoding the inflammatory cytokines TNF- $\alpha$ and IL- $1 \beta$ in QD-labeled RAW 264.7 cells were examined. The results (Fig. 2) indicated that QDs at $50 \mu \mathrm{g} / \mathrm{ml}$ significantly increased mRNA expression levels of TNF- $\alpha$ (4.2-fold change) and IL-1 $\beta$ (21.5-fold change) in the macrophages. When the
QD concentration was $100 \mu \mathrm{g} / \mathrm{ml}$, the expression of TNF- $\alpha$ mRNA was significantly increased, compared with the 0 $(\mathrm{P}=0.04328)$ and $50 \mu \mathrm{g} / \mathrm{ml}$ groups $(\mathrm{P}=0.00032)$; additionally, $100 \mu \mathrm{g} / \mathrm{ml}$ QDs increased IL- $1 \beta$ mRNA expression levels, compared with the 0 and $50 \mu \mathrm{g} / \mathrm{ml}$ groups, but this was only significantly increased compared with the $0 \mu \mathrm{g} / \mathrm{ml}$ group $(\mathrm{P}=0.00016)$. The results indicated that $\mathrm{QDs}$ have the ability to activate macrophages, thus promoting the secretion of certain inflammatory factors.

QDs promote the proliferation of macrophages. Cell proliferation is an important biological property of macrophages, which, to a certain extent, reflects the activation state of macrophages. The results of the CCK- 8 assay demonstrated that co-culture with $50 \mu \mathrm{g} / \mathrm{ml}$ QDs significantly increased the proliferation of RAW 264.7 cells, compared with the 0 $\mu \mathrm{g} / \mathrm{ml}$ group. However, at concentration of $100 \mu \mathrm{g} / \mathrm{ml}$ QDs, the proliferation was similar to that of the $50 \mu \mathrm{g} / \mathrm{ml}$ QDs and was only significantly different when compared with the $0 \mu \mathrm{g} / \mathrm{ml}$ group $(100 \mu \mathrm{g} / \mathrm{ml}: \mathrm{P}=0.04681 ; 50 \mu \mathrm{g} / \mathrm{ml}: \mathrm{P}=0.04329 ;$ Fig. 3$)$. The results indicated that QDs have the ability to increase the proliferation of macrophages.

Impact of QDs on the apoptosis of macrophages. Apoptosis initiates cell death (19), and is notably associated with cell biological functions including activation and proliferation (20). The results of annexin $\mathrm{V}$ labeling (Fig. 4) demonstrated that QDs were not able to increase the apoptosis rate of RAW 264.7 cells. When the concentration of QDs was $100 \mu \mathrm{g} / \mathrm{ml}$, the apoptosis rate of RAW 264.7 cells decreased from $1.43 \%$ (0 $\mu \mathrm{g} / \mathrm{ml}$ group) to $1.14 \%(50 \mu \mathrm{g} / \mathrm{ml}$ group) and $0.94 \%$ (100 $\mu \mathrm{g} / \mathrm{ml}$ group), indicating that QDs do not promote the apoptosis of macrophages.

\section{Discussion}

In the present study, it was determined that CdSe/ZnS QDs could be phagocytosed by macrophages. The co-culture of QDs and macrophages did not lead to an increase in the apoptosis of RAW 264.7 cells. This indicated that CdSe/ZnS QDs could be used as tracers.

As a novel type of nanoparticle material, QDs have notable prospects in biomedical fields for in vivo labeling and tracing, as well as for in vitro multi-fluorescence labeling; however, a number of previous studies have identified in vivo toxicity of QDs (21-23). The cytotoxicity of CdSe and CdSe/ZnS nanoparticles has been investigated for different surface modifications, including coating with mercaptopropionic acid, silanization and polymer coating (24), when targeting liver cells, red blood cells and other cell types $(25,26)$. The cytotoxicity of $\mathrm{Cd} / \mathrm{Se}$ QDs or Cd/Te QDs is mainly associated with the $\mathrm{Cd}^{2+}$ ions carried in QDs that produce oxidative free radicals. Heavy metal $\mathrm{Cd}^{2+}$ ions exhibit cell toxicity through a variety of mechanisms, such as interfering with cellular DNA repair and promoting oxidative stress. Furthermore, the cytotoxicity of QDs is notably associated with multiple parameters, including the particle size, the number of surface charges, the redox activity, the surface coating component, the mechanical stability of QDs and the external environmental conditions $(27,28)$. It has been demonstrated that the toxicity 

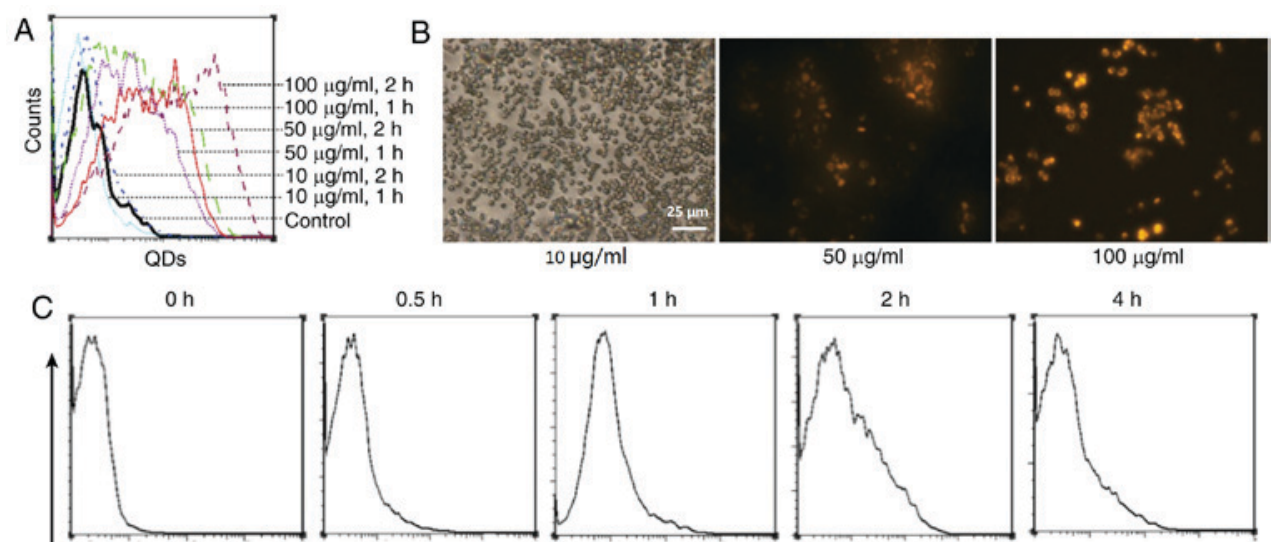

$10 \mu \mathrm{g} / \mathrm{m}$

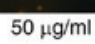

$100 \mu \mathrm{g} / \mathrm{ml}$
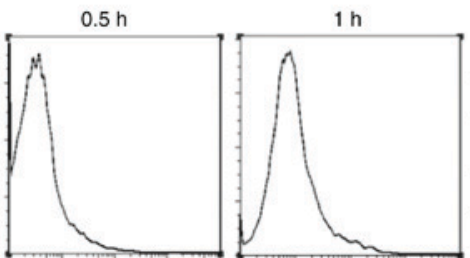

$2 \mathrm{~h}$

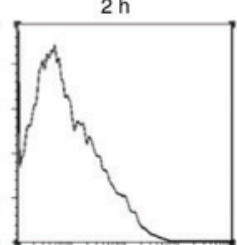

$4 \mathrm{~h}$
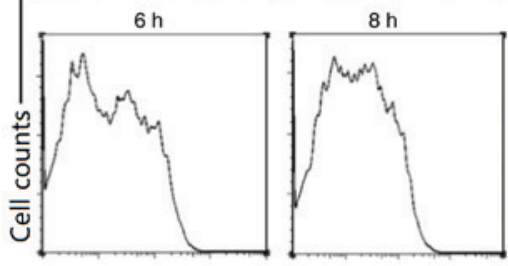

$16 \mathrm{~h}$

$18 \mathrm{~h}$

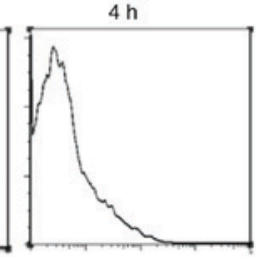

$24 \mathrm{~h}$

Fluorescence intensity
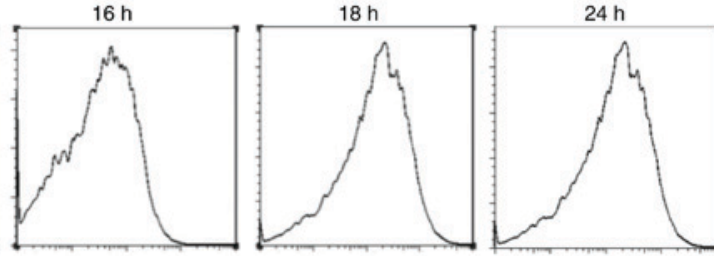

$\longrightarrow$

Figure 1. In vitro labeling of macrophages using QDs. (A) QD signals from flow cytometry, demonstrate that the co-culture of RAW 264.7 cells with QDs enabled the macrophages to become labeled with fluorescent signal. (B) Images of RAW 246.7 cells and various QD concentrations under a fluorescence microscope, which also demonstrated that the macrophages exhibited strong fluorescence signals following engulfment of QDs. (C) QDs-labeled macrophages were analyzed using a flow cytometer at different time points, reaching a peak at $18 \mathrm{~h}$. QDs, quantum dots.
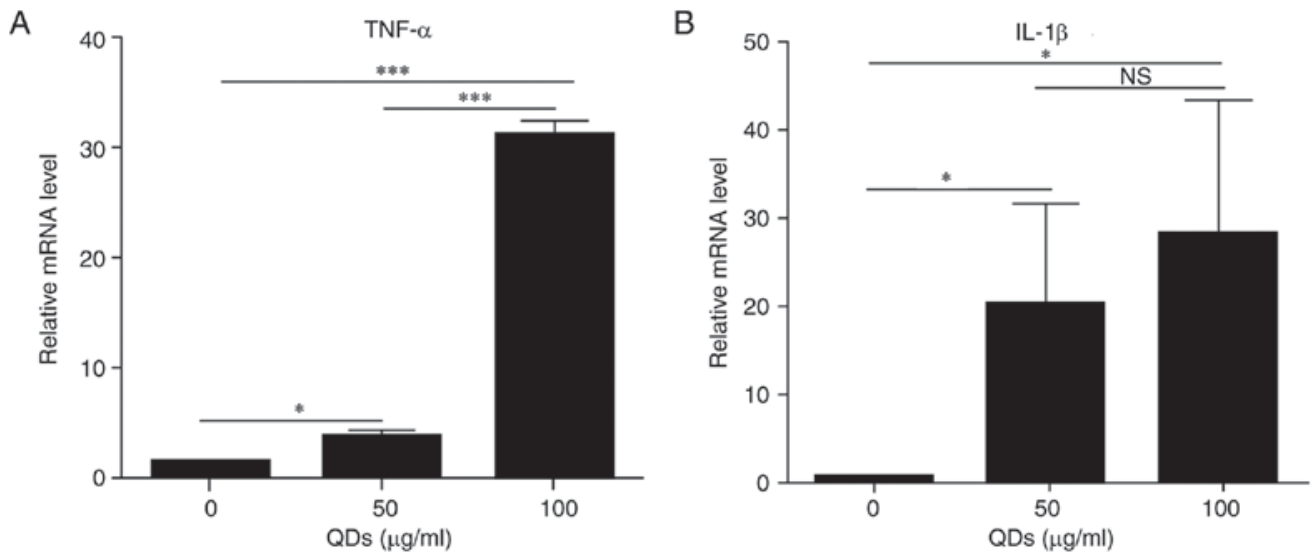

Figure 2. QD co-culture induces macrophages to secrete inflammatory cytokines, which increased with the concentration of QDs increasing. (A) TNF- $\alpha$. (B) IL-1 ${ }^{*} \mathrm{P}<0.05$ and ${ }^{* * *} \mathrm{P}<0.01$. QDs, quantum dots; TNF- $\alpha$, tumor necrosis factor- $\alpha$; IL-1 $\beta$, interleukin- $\beta$; NS, not significant.

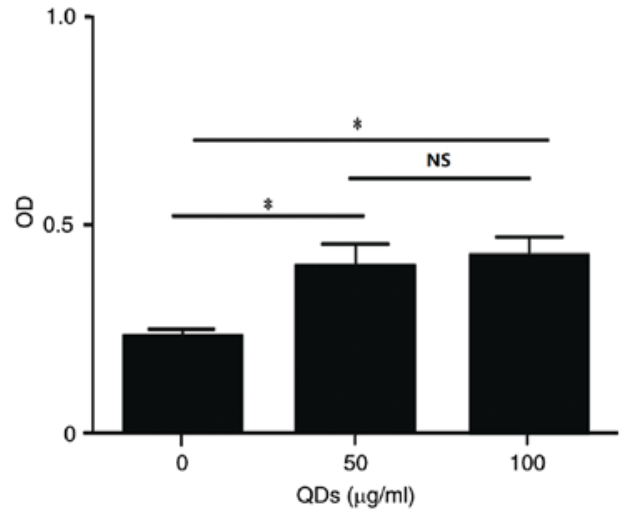

Figure 3. Effects of QDs on the proliferation of macrophages, the higher the concentration of QDs, the higher the OD value. " $\mathrm{P}<0.05$. OD, optical density; NS, not significant; QDs, quantum dots. and biological activities of QDs are associated mainly with their surface coating materials (29). Primarily, when QDs are coated with cytotoxic reagents, significant toxicity is observed; however, when they are coated with bioactive materials, the QDs exhibited the biological characteristics of the conjugates, with decreased toxicity (30). For example, $\beta$-cyclodextrin-modified Cd/Se QDs exhibited a broader light spectrum and lower cytotoxicity compared with Cd/Se QDs alone (31).

The results of the present in vitro study indicated that QDs could be engulfed effectively by macrophages, thus marking them with fluorescence signals. This labeling process is notably associated with the concentration and incubation time of the QDs; however, the increase in mRNA expression levels of TNF- $\alpha$ and IL-1 $\beta$ indicated that the intake of QDs was also able to promote macrophages to 


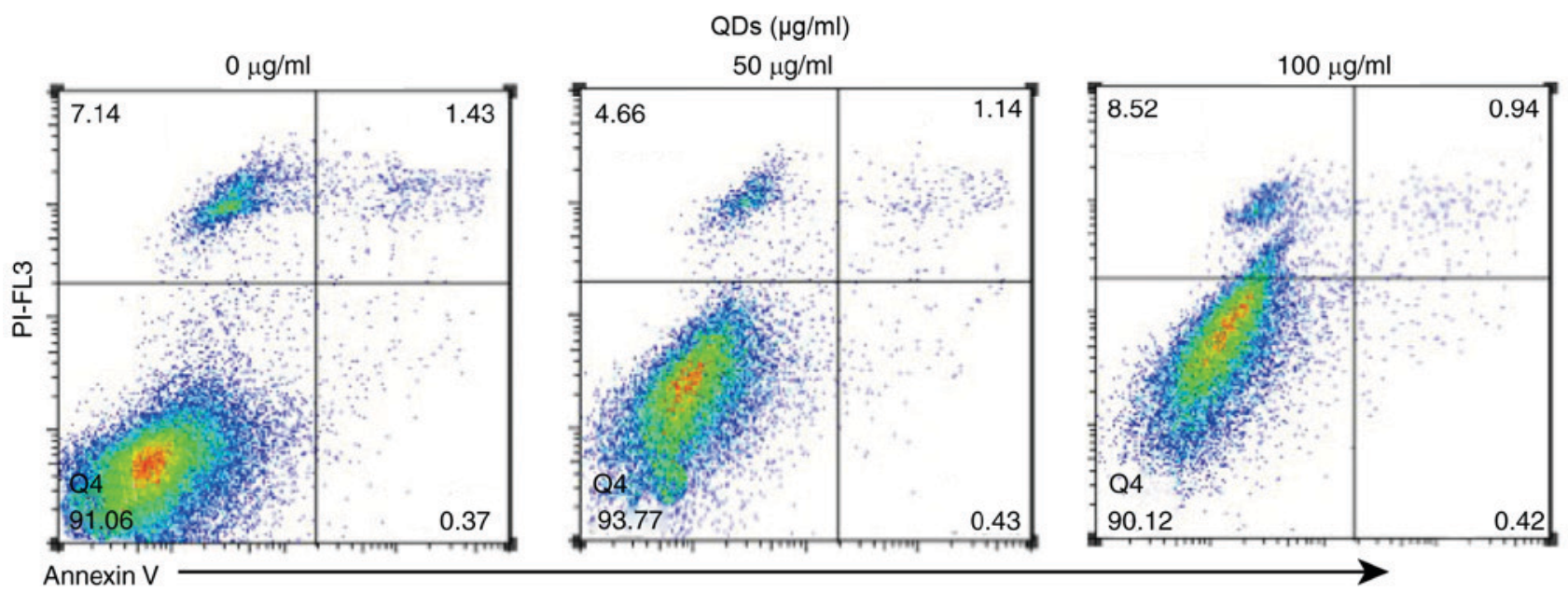

Figure 4. Effects of QDs on the apoptosis of macrophages, which demonstrate the apoptosis rate of RAW 264.7 cells decreased from $1.43 \%(0 \mu \mathrm{g} / \mathrm{ml}$ group $)$ to $1.14 \%$ (50 $\mu \mathrm{g} / \mathrm{ml}$ group) and $0.94 \%$ (100 $\mu \mathrm{g} / \mathrm{ml}$ group) and indicate that QDs do not promote the apoptosis of macrophages. QDs, quantum dots; PI-FL3; propidium iodide.

secrete inflammatory cytokines, which could promote cell proliferation, while having no significant effect on apoptosis. When QDs are coated with bioactive molecules, their activation of macrophages may be decreased; therefore, when QDs are used for in vivo labeling and tracing, their macrophage-activating effect would be decreased with less macrophages activated to prolong their in vivo labeling duration (10). The results of that study are agreement with the present results.

The biocompatibilities of QDs with macrophages are also beneficial for the treatment of macrophage-associated diseases and to regulate the immune system. $\mathrm{CdSe} / \mathrm{CdS} / \mathrm{ZnS}$ QDs cross-linked to Adriamycin can be engulfed by alveolar macrophages in the lungs, the accumulation of Adriamycin by alveolar macrophages would thus induce apoptosis (32). In this process, the phagocytosis of QDs by macrophages is exploited to form effective carriers for in vivo macrophage-targeted therapies (33). A variety of pattern-recognition receptors are expressed on the surface of macrophage. When these receptors bind with their corresponding ligands, such as Toll-like receptors, macrophages can be effectively activated, thus causing immunomodulatory effects (33). Lipopolysaccharide (LPS)-QDs, prepared by cross-linking the pattern-recognition molecule Kdo2-Lipid A, an LPS from Escherichia coli, with QDs, were engulfed by macrophages, resulting in their in vitro activation, which may have immunomodulatory effects in vivo (34). In addition, when the novel anti-tuberculosis drug Zn-RIF, a complex of zinc with rifampicin, was combined with transferrin protein-coupled silver QDs, Zn-RIF-Tf-QD, targeting was towards the inner macrophages improved, and the anti-tuberculosis activity was increased $>10$-fold (35). The results of these studies are consistent with the theory that the biocompatibility of QDs and macrophages, and the phagocytosis of QDs, does not result in apoptosis, and that different modifications may promote cell proliferation.

In conclusion, the results of the present study supported the hypothesis that macrophages engulf QDs effectively in vitro. The surface of QDs can be modified with different molecules according to the application purposes, such as to prolong the in vivo duration of QDs or to use QDs as carriers to cause the targeted activation of macrophages.

The limitations of the present study included: Using a single monocyte/macrophage cell line, which limited its value for extrapolation into potential clinical applications of QDs; and that the protein levels of TNF- $\alpha$ and IL-1 $\beta$ were measured in the cells, but not in culture supernatants. Since it is possible that inflammatory factors may be released into the culture supernatant, a measure including secreted factors may be more accurate.

\section{Acknowledgements}

Not applicable.

\section{Funding}

No funding was received.

\section{Availability of data and materials}

All data generated or analyzed during the present study are included in this published article.

\section{Authors' contributions}

CL designed the experiment and wrote the manuscript. PZ, $\mathrm{YH}, \mathrm{DH}, \mathrm{YS}$ and RL performed the experiment. YH and RL evaluated the experiment. DH performed experimental data collection. YH reviewed the manuscript thoroughly.

\section{Ethics approval and consent to participate}

Not applicable.

\section{Patient consent for publication}

Not applicable. 


\section{Competing interests}

The authors declare that they have no competing interests.

\section{References}

1. Hild WA,Breunig Mand Goepferich A: Quantum dots-nano-sized probes for the exploration of cellular and intracellular targeting. Eur J Pharm Biopharm 68: 153-168, 2008.

2. Michalet X, Pinaud FF, Bentolila LA, Tsay JM, Doose S, Li JJ, Sundaresan G, Wu AM, Gambhir SS and Weiss S: Quantum dots for live cells, in vivo, imaging, and diagnostics. Science 307: 538-544, 2005

3. Joo KI, Fang Y, Liu Y, Xiao L, Gu Z, Tai A, Lee CL, Tang Y and Wang P: Enhanced real-time monitoring of adeno-associated virus trafficking by virus-quantum dot conjugates. ACS Nano 5 : 3523-3535, 2011.

4. Abbasi E, Kafshdooz T, Bakhtiary M, Nikzamir N, Nikzamir N, Nikzamir M, Mohammadian M and Akbarzadeh A: Biomedical and biological applications of quantum dots. Artif Cells Nanomed Biotechnol 44: 885-891, 2016.

5. Kamila S, McEwan C, Costley D, Atchison J, Sheng Y, Hamilton GR, Fowley C and Callan JF: Diagnostic and therapeutic applications of quantum dots in nanomedicine. Top Curr Chem 370: 203-224, 2016.

6. Delehanty JB, Mattoussi H and Medintz IL: Delivering quantum dots into cells: Strategies, progress and remaining issues. Anal Bioanal Chem 393: 1091-1105, 2009.

7. Farlow J, Seo D, Broaders KE, Taylor MJ, Gartner ZJ and Jun YW: Formation of targeted monovalent quantum dots by steric exclusion. Nat Methods 10: 1203-1205, 2013.

8. Bajwa N, Mehra NK, Jain K and Jain NK: Pharmaceutical and biomedical applications of quantum dots. Artif Cells Nanomed Biotechnol 44: 758-768, 2016.

9. Cesar CL: Quantum dots as biophotonics tools. Methods Mol Biol 1199: 3-9, 2014

10. Jayagopal A, Su YR, Blakemore JL, Linton MF, Fazio S and Haselton FR: Quantum dot mediated imaging of atherosclerosis. Nanotechnology 20: 165102, 2009.

11. Rabolli V, Lison D and Huaux F: The complex cascade of cellular events governing inflammasome activation and IL-1 $\beta$ processing in response to inhaled particles. Part Fibre Toxicol 13: 40, 2016.

12. Egners A, Erdem $M$ and Cramer T: The response of macrophages and neutrophils to hypoxia in the context of cancer and other inflammatory diseases. Mediators Inflamm 2016: 2053646, 2016.

13. Kaur S, Raggatt LJ, Batoon L, Hume DA, Levesque JP and Pettit AR: Role of bone marrow macrophages in controlling homeostasis and repair in bone and bone marrow niches. Semin Cell Dev Biol 61: 12-21, 2016.

14. Patel U, Rajasingh S, Samanta S, Cao T, Dawn B and Rajasingh J: Macrophage polarization in response to epigenetic modifiers during infection and inflammation. Drug Discov Today 22 186-193, 2016.

15. Liu Q, Li H, Xia Q, Liu Y and Xiao K: Role of surface charge in determining the biological effects of $\mathrm{CdSe} / \mathrm{ZnS}$ quantum dots. Int J Nanomedicine 10: 7073-7088, 2015.

16. Xiao Y, Zijl S, Wang L, de Groot DC, van Tol MJ, Lankester AC and Borst J: Identification of the common origins of osteoclasts, macrophages, and dendritic cells in human hematopoiesis. Stem Cell Reports 4: 984-994, 2015.

17. Livak KJ and Schmittgen TD: Analysis of relative gene expression data using real-time quantitative PCR and the 2(-Delta Delta C(T)) method. Methods 25: 402-408, 2001.
18. Mohamed MM, El-Ghonaimy EA, Nouh MA, Schneider RJ, Sloane BF and El-Shinawi M: Cytokines secreted by macrophages isolated from tumor microenvironment of inflammatory breast cancer patients possess chemotactic properties. Int J Biochem Cell Biol 46: 138-147, 2014.

19. Donjerković D and Scott DW: Activation-induced cell death in B lymphocytes. Cell Res 10: 179-192, 2000.

20. Galluzzi L, Kepp O, Trojel-Hansen C and Kroemer G: Non-apoptotic functions of apoptosis-regulatory proteins. EMBO Rep 13: 322-330, 2012.

21. $\mathrm{Wu} \mathrm{T}$ and Tang M: Toxicity of quantum dots on respiratory system. Inhal Toxicol 26: 128-139, 2014.

22. Chong Y, Ma Y, Shen H, Tu X, Zhou X, Xu J, Dai J, Fan S and Zhang $\mathrm{Z}$ : The in vitro and in vivo toxicity of graphene quantum dots. Biomaterials 35: 5041-5048, 2014.

23. Hauck TS, Anderson RE, Fischer HC, Newbigging $S$ and Chan WC: In vivo quantum-dot toxicity assessment. Small 6: 138-144, 2010.

24. Kirchner C, Liedl T, Kudera S, Pellegrino T, Muñoz Javier A, Gaub HE, Stölzle S, Fertig N and Parak WJ: Cytotoxicity of colloidal CdSe and CdSe/ZnS nanoparticles. Nano Lett 5: 331-338, 2005.

25. Hardman R: A toxicologic review of quantum dots: Toxicity depends on physicochemical and environmental factors. Environ Health Perspect 114: 165-172, 2006.

26. Qu G, Wang X, Wang Z, Liu S and Jiang G: Cytotoxicity of quantum dots and graphene oxide to erythroid cells and macrophages. Nanoscale Res Lett 8: 198, 2013.

27. Lin $\mathrm{CH}$, Chang LW, Wei $\mathrm{YH}$, Wu SB, Yang CS, Chang WH, Chen YC and Lin PP: Electronic microscopy evidence for mitochondria as targets for $\mathrm{Cd} / \mathrm{Se} / \mathrm{Te}$-based quantum dot 705 toxicity in vivo. Kaohsiung J Med Sci 28: S53-S62, 2012.

28. Smith WE, Brownell J, White CC, Afsharinejad Z, Tsai J, Hu X, Polyak SJ, Gao X, Kavanagh TJ and Eaton DL: In vitro toxicity assessment of amphiphillic polymer-coated CdSe/ZnS quantum dots in two human liver cell models. ACS Nano 6: 9475-9484, 2012.

29. Zhang W, Yang L, Kuang H, Yang P, Aguilar ZP, Wang A, Fu F and $\mathrm{Xu} \mathrm{H}$ : Acute toxicity of quantum dots on late pregnancy mice: Effects of nanoscale size and surface coating. J Hazard Mater 318: 61-69, 2016.

30. Bakalova R, Zhelev Z, Kokuryo D, Spasov L, Aoki I and Saga T: Chemical nature and structure of organic coating of quantum dots is crucial for their application in imaging diagnostics. Int J Nanomedicine 6: 1719-1732, 2011

31. Guleria A, Rath MC, Singh AK and Adhikari S: Rapid and one-pot synthesis of self-assembled CdSe quantum dots functionalized with $\beta$-Cyclodextrin: Reduced cytotoxicity and band gap engineering. J Nanosci Nanotechnol 15: 9341-9357, 2015.

32. Chakravarthy KV, Davidson BA, Helinski JD, Ding H, Law WC, Yong KT, Prasad PN and Knight PR: Doxorubicin-conjugated quantum dots to target alveolar macrophages and inflammation. Nanomedicine 7: 88-96, 2011.

33. Yeo JC, Wall AA, Luo L, Condon ND and Stow JL: Distinct roles for APPL1 and APPL2 in regulating toll-like receptor 4 signaling in macrophages. Traffic 17: 1014-1026, 2016.

34. Barr TA, Krembuszewski M, Gupta M, Gray D and Mareque-Rivas JC: Quantum dots decorated with pathogen associated molecular patterns as fluorescent synthetic pathogen models. Mol Biosyst 6: 1572-1575, 2010.

35. Pati R, Sahu R, Panda J and Sonawane A: Encapsulation of zinc-rifampicin complex into transferrin-conjugated silver quantum-dots improves its antimycobacterial activity and stability and facilitates drug delivery into macrophages. Sci Rep 6: 24184, 2016. 